\title{
Phycoremediation of Metal Pollution of Wastewater
}

\author{
Amany F. Hasaballah ${ }^{1}$, T. A. Hegazy, M. S. Ibrahim, and Doaa A. El-Emam \\ Environmental Sciences Department, \\ Faculty of Science, Damietta University \\ Damietta City, Egypt.
}

\begin{abstract}
Huge interest has recently arisen toward using various kinds of inexpensive and available alternative techniques for wastewater treatment and removal of heavy metals. One of them is the usage of ready biomass of several kinds of algae (macroalgae and microalgae). This study focused on applying the phycoremediation technology as an alternative, eco-friendly technology for wastewater treatment. We examine the potential of Chlorella vulgaris and Scenedesmus quadricauda (microalgae) and the brown macroalga, Dictyota dichotoma and Turbinaria ornata in this technology, (pilot-scale laboratory study). We analyzed the physicochemical characteristic of wastewater before and after treatment with algae and determine the removal capacity of algae for contaminated heavy metals. The results obtained showed that the maximum growth rate, growth index and biomass productivity were obtained at $10^{6} \mathrm{cell} / \mathrm{ml}$ concentration which was recommended to be used in wastewater treatment. Microalgae pollutants removal efficiency was reached to 92.7 and $87.5 \%$ for BOD and COD, respectively and $100 \%$ for $\mathrm{TN}$ and $\mathrm{TP}$. While of Turbinaria ornata reached to $44.4,29.3,37.8,84.2,65.3,67.5,67.8$, and $67.1 \%$ for TDS, salinity, conductivity, turbidity, BOD, COD, TN and TP, respectively, but of Dictyota dichotoma reached to $52.3,39.3,50.6,95.3,72.1,71.3,73.5$ and $70.4 \%$, respectively. In similar way removal percent of metal pollution by microalgae reached to $(98.8,90.4,83.9,75.7,99.8$, 99.7 and $99.5 \%$ ) for $\mathrm{Cu}, \mathrm{Zn}, \mathrm{Cd}, \mathrm{Ni}, \mathrm{Co}, \mathrm{Fe}$ and $\mathrm{Pb}$. While, Turbinaria ornata recorded removal percent $(55.5,70.9,59.8$, 57.6, 55.1, 72.6 and $42.1 \%$ ) for $\mathrm{Cd}, \mathrm{Cu}, \mathrm{Pb}, \mathrm{Fe}, \mathrm{Co}, \mathrm{Zn}$ and $\mathrm{Ni}$, respectively, and Dictyota dichotoma recorded removal percent $(34.2,40.7,68.3,72.7,57.8,70.5$ and $52.1 \%)$ for $\mathrm{Ni}$, $\mathrm{Zn}, \mathrm{Cd}, \mathrm{Cu}, \mathrm{Pb}, \mathrm{Fe}$, and $\mathrm{Co}$, respectively.
\end{abstract}

Keywords - Phycoremediation, algae, biosorption, heavy metals, wastewater.

\section{INTRODUCTION}

The rapid increase in population, industrialization, and urbanization has resulted in the disposal of various pollutants into the water bodies. This discharged effluent is of great concern because it has a toxic or carcinogenic effect on human and living species. Heavy metals for instance, which is widely produced and extremely toxic in relatively low dosages and also recalcitrant and persistent in the environment. Therefore, the removal of these toxins from water prior to supplying water for drinking, bathing, etc. is very important and urgent. There is a wide range of treatment technologies ( physical, chemical and biological) such as chemical precipitation, coagulation-flocculation, flotation, ion exchange, and membrane filtration, bioremediation, ozonation and more .most of these current conventional methods for water treatment require high energy requirements, high operation, and maintenance, cannot effectively respond to diurnal, seasonal, or longterm variations in the composition of wastewater and produce large volumes of sludge which, make them economically unviable for many regions,[1]. This makes researchers investigate a new alternative, eco-friendly technology for wastewater treatment. Phycoremediation is the use of algae for the removal or biotransformation of pollutants from wastewater, [2]. It is considered as an ecosolution to environmental protection and sustainable remediation, [3].

FU and Wang [4], proved with evidence from the literature survey of 185 articles that biosorption is recognized as an effective and economical method for low concentration heavy metal wastewater treatment as an alternative and can remove heavy metal ions with high efficiency, more than that processes which have been widely used to remove metals from wastewater.

Many investigations proved that microalgae provides a pathway for the removal of nitrogen, phosphorus, carbon dioxide, heavy metals and pathogens present in wastewaters which necessary for their growth. It also, saves and reduces requirements for chemical remediation and minimizes freshwater use for biomass production as part of a wastewater treatment process. Consequently, it is a promising and advantageous process where faster growth rate accompanied by an elimination of water contamination level, [5].

Previous studies registered the remarkable potential of Chlorella vulgaris in wastewater treatment. Keffer and Kleinheinz [6], recorded that, it fixed up to $74 \%$ carbon dioxide when grown in a photo-bioreactor, and in absorbing 45-97\% nitrogen, 28-96\% phosphorus and in reducing the chemical oxygen demand (COD) by $61-86 \%$ from different type of wastewater such as textile, sewage, municipal ,agricultural and recalcitrant, [7].

Ezenweani et al. [3], recorded that both microalgae removed between 88 and $94 \%$ of phosphates and removed 83 and $99 \%$ of ammonium and also reduced the concentration of iron by $71 \%$ while potassium went down by 70 to $77 \%$. Furthermore, the performance of $C$. Vulgaris in synthesized wastewater was improved when co-immobilized alginate beads with microalgae growth promotions and Scenedesmus, which removed $100 \%$ of ammonium during four consecutive cycles of $48 \mathrm{~h}$, and $83 \%$ for phosphorus after one cycle of $48 \mathrm{~h}$. Thus, Chlorella vulgaris is considered as one of the best 
microalgae for bioremediation of wastewater with an impressive potential to completely remove ammonium and sometimes modest potential to eliminate phosphorus present in the medium, [8]. The metal uptake capacity of algal biomass depends on the availability of polysaccharide contents such as alginates and fucoidans on the cell surface, [9].

According to Vigneshwaran et al. [10], biosorption of metals is a two-step process. First, the metals ions bind and, second, the metal ions accumulate on the binding sites. It was thought that marine brown alga has rich content of extracellular polysaccharide which enables it to exhibit prosperous metal sorption compared to other algal species. Seaweed (macroalgae) collected from the ocean has shown impressive biosorption of metals. Brown algae, especially, contain high amounts of alginate, which are well protected within brown algae's cellular structures, and copious carboxylic groups capable of capturing cations present in solutions, [11]. This proved by Yasser $\boldsymbol{e t}$ al. [12] as he founded that the sorption capacity of Dictyota dichotoma biomass for the removal of Cd (II) is higher than that of the majority of other adsorbents which reported in the literature. Also, he mentions to the variation of the sorption capacity which depends on the characteristics of the individual adsorbent, the extent of surface/surface modification and the initial concentration of the adsorbate. On the other hand, Senthilkumar $\boldsymbol{e t}$ al. [13] Confirmed, seaweeds have proved to be the most efficient and practical biomass for the removal of heavy metal ions from aqueous solutions. He also thought it is an ideal candidate for heavy metal removal in both batch and column operations because of its compatibility with almost all heavy metal ions, its macroscopic appearance, rigidity, and easy availability. Its polysaccharide content is believed to be responsible for its excellent metal binding capacity. Accordingly, there is a real need for treatment with algae that offer alternative technology. Using algae for wastewater treatment offers some interesting advantages over conventional wastewater treatment such as in; Costeffectiveness and safety, Green House Gas emission reduction, Reductions in sludge formation and low energy requirement, Production of algal biomass, Oxygenation of the systems through photosynthesis thereby enabling effective decomposition, Effective reduction of nutrient load and consequent total dissolved solids as these are used up as nutrient sources, Production of high algal biomass which can be used as feed in aquaculture and as biofertilizer, Simple operation, and maintenance, Potential for energy and nutrient recovery,[11]. This study aimed to investigate the biosorption potential of Dictyota dichotoma and Turbinaria ornata biomass and evaluate the capacity of two microalgae species, Chlorella vulgaris and Scenedesmus quadricauda to remove organic and inorganic pollutants and heavy metals from wastewater. Optimum biosorption conditions were determined as a function of $\mathrm{pH}$, biomass dosage, contact time and temperature.

\section{MATERIALS AND METHODS}

\section{Algae and wastewater}

The wastewater was a composite sample of raw water from Damietta branch-Nile River which collected from different 12 polluted sites along it. The wastewater was collected and its main physicochemical characteristics were analyzed: $\mathrm{pH}$, chemical oxygen demand (COD), biochemical oxygen demand (BOD), Total phosphorus (TP), dissolved oxygen (DO), total nitrogen (TN) and some heavy metals.

Preservation methods were limited to $\mathrm{pH}$ control, chemical addition, refrigeration, and freezing, [14]. $\mathrm{pH}$ value of the samples was measured directly by $\mathrm{pH}$ Meter (model, 211 HANNA,.USA) according to the electrometric method, [15]. While Turbidity of samples was measured by the Nephelometric Method using (A11000 Turbidimeter, aqualytic, Germany with measuring 0-200 NTU) according to APHA [15]. Where total dissolved solids (TDS), Salinity and Electrical conductivity (EC) were measured by TDS meter (Digital Portable TDS/ Conductivity meter Model. 8033 HANNA, USA) as TDS expressed as ppm (mg/l) and expressed as $\mathrm{ds} / \mathrm{m}$. Dissolved oxygen (DO) in the water sample was detected according to Winkler with azide modification method, APHA [15]. Biological oxygen demand (BOD) of the samples was determined according to Adams [16] where chemical oxygen demand (COD) of the samples was determined by Manual Method: Dichromate Reflux according to EPA [14]. On the other hand, Nitrite ions and Total Nitrogen (TN) were determined according to Rump Method [17] and microKjeldahl method but total phosphate (TP) of the samples was detected according to Ascorbic Acid Method [15]. However heavy metals analysis of water samples $(\mathrm{Cd}, \mathrm{Cu}$, $\mathrm{Pb}, \mathrm{Fe}, \mathrm{Co}, \mathrm{Zn}$, and $\mathrm{Ni}$ ) were carried out according to Yasser et al. [12].

\section{Preparation of microalgae}

Tests were carried out using two species of microalgae, Chlorella vulgaris and Scenedesmus quadricauda, both supplied by Botany and Microbiology Department, Faculty of Science, Damietta University.

Initial stock cultures of Chlorella vulgaris and Scenedesmus quadricauda sp. were maintained in the modified Bold Basal medium [18] which containing the following chemicals: $\mathrm{NaNO}_{3}, \mathrm{CaCl}_{2} .2 \mathrm{H}_{2} \mathrm{O}, \mathrm{MgSO}_{4} .7 \mathrm{H}_{2} \mathrm{O}$, $\mathrm{K}_{2} \mathrm{HPO}_{4}, \mathrm{KH}_{2} \mathrm{PO}_{4}, \mathrm{NaCl}$, EDTA, KOH, FeSO $4.7 \mathrm{H}_{2} \mathrm{O}$, $\mathrm{H}_{2} \mathrm{SO}_{4}$, and micronutrients. The culture was inoculated in outdoor conditions for 30 days. Prior to inoculation, microalgae cultures were harvested using a centrifuge at low speed $(3500 \mathrm{rpm})$ for ten minutes and washed three times with sterilized distilled water. This was followed by cell observation and cell concentration count using Neubauer Haemocytometer.

A total of 5 glass vessels $(500 \mathrm{ml})$ were filled with $300 \mathrm{ml}$ of Nile raw water which was used in this experiment as the wastewater. Three wastewater experiment glass vessels (triplicate) were inoculated with microalgae starting with an initial cell concentration of $10^{3}$ cells $/ \mathrm{ml}$ (population A) 
based on the standard methods [15], $10^{6}$ cell $/ \mathrm{ml}$ (population B) according to Gani et al. [19] and $10^{7}$ cell/ml (population C) Kothari et al. [20]. The other two glass vessels used as indicator, one of it had not been inoculated with any microalgae (Blank) and the other was control (population D). The glass vessels were covered with sterile cotton plugs and kept under outdoor natural condition during the experimental period. All samples were shaken from time to time to ensure that the microalgae were uniformly homogenized in the wastewater.

\section{Determination of growth rate}

The reduction in the pollution load was observed as a function of the increase in the growth rate of microalgae. The growth rate of microalgae was determined according to tow method for insurance. In first one, samples were taken from the culture for cell growth counting in wastewater using Haemocytometer with interval 48 hours according to Komolafe et al. [21] then the growth of microalgae was determined according to the specific growth rate $(\mu /$ day $)$

\section{Specific growth rate $(\mu /$ day $)=\ln \left(\mathrm{C}_{\mathrm{f}} / \mathrm{C}_{\mathrm{i}}\right) /\left(\mathrm{T}_{\mathrm{f}}-\mathrm{T}_{\mathrm{i}}\right)$ Eq. 1 \\ Where \\ $\mathrm{C}_{\mathrm{f}}$ and $\mathrm{C}_{\mathrm{i}}$ were defined as the cell concentration (cell.ml $\mathrm{m}^{-1}$ ) at time $\mathrm{T}_{\mathrm{f}}$ and $\mathrm{T}_{\mathrm{i}}$, respectively.}

While in the second method growth was measured every 48 hours using a spectrophotometer at a wavelength of 550 nm.

The data were expressed in agreement with Eze et al. [22] according to the following relation:

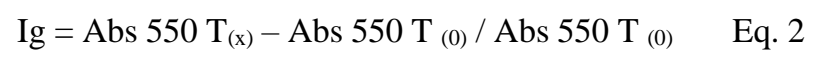

Where

Ig
$\begin{array}{ll}\text { Abs550 } \mathrm{T}_{(\mathrm{x})} & \text { the growth index } \\ \text { absorbance of the 550-nm wavelength at } \\ \text { time } \mathrm{x}\end{array}$
$\begin{array}{ll}\text { Abs550 } \mathrm{T}_{(0)} & \text { absorbance of the } 550-\mathrm{nm} \text { wavelength at } \\ \text { time } 0 & \end{array}$

\section{Preparation of macroalgae}

The raw biomass of Dictyota dichotoma and Turbinaria ornata_was harvested from the red sea beach (coast of Hurghada north east Egypt). The samples were washed with deionized water to remove extraneous materials and common ions present in seawater. The washed biomass was dried at $70^{\circ} \mathrm{C}$ for $48 \mathrm{~h}$. The dried algae biomass was grinded, sieved and then the particles with an average size less than $0.1 \mathrm{~mm}, 0.1 \mathrm{~mm}, 0.5 \mathrm{~mm}$, $0.7 \mathrm{~mm}$ and $1 \mathrm{~mm}$ were examined to select the optimum texture which can be used for biosorption experiments. The biosorption experimental parameters (temperature, $\mathrm{pH}$ value, retention time and biomass dosage and texture) were optimized for reaching the equilibrium condition. $3 \mathrm{~g} / \mathrm{l}$ of the biomass was added in the measuring baker with water and were shaken in an electrical flocculator at $150 \mathrm{rpm}$ for contact time (20-30 mins) at $\mathrm{pH} 6.5$ and temperature of $20 \circ$ C.The contents of the measuring baker were filtered through filter paper and the filtrate was analyzed for metal concentration by using the Inductively Coupled PlasmaMass Spectrometry (ICP-OES 7000) was used for heavy metal analysis with an ultrasonic nebulizer (USN), this nebulizer decrease the instrumental detection limits by $10 \%$, this ICP instrument is Perkin Elmer Optima 3000, USA.

The biosorption potential percent of algae for metal ion and the main physicochemical parameters was calculated as follows:

$$
\text { Biosorption potential }(\%)=((\mathrm{Hi}-\mathrm{Hf}) / \mathrm{Hi}) \times 100
$$

Where Hi and Hf are the initial and final concentrations before and after treatment, respectively.

Another technique has been used for the investigation and to improve the biosorption of heavy metals by macroalgae according to Suparna $\boldsymbol{e t}$ al. [23]. The difference between the concentrations of heavy metals would be an indicator for biosorption potential of algae. The increase occurred in heavy metals accumulation in algae after usage, will used as indicator for biosorption potential of macroalgae.

\section{RESULT AND DISCUSSION}

The nutrient supplements required for microalgae growth depend on wastewater characteristics. The physical and chemical parameters of wastewater used in this study compared to the effluent standard which has been used in the formation of culture media in microalgae growth in previous researches, Table 1. The $\mathrm{pH}$ value was in acceptable concentration compared to the effluent standard 5 and standard 4 and suitable for microalgae cultivation, [24]. The concentration of DO, BOD and COD in this study was $6.53,23.37$ and $62.55 \mathrm{mg} / \mathrm{L}$, respectively, and these concentrations were in the limited range compared to the other standards. The wastewater used also contained $2.8 \mathrm{mg} / \mathrm{L}$ of $\mathrm{TP}$ and $1.4 \mathrm{mg} / \mathrm{L}$ of $\mathrm{TN}$, which was below standard limits. TP was acceptable compared to studies conducted by Kothari et al. [29], Zhang et al. [36] and Gani et al. [19], as they founded that TP was 3.4, 1.59 and $3.27 \mathrm{mg} / \mathrm{L}$, respectively. Other parameters were also determined such as TDS which was $40.3 \mathrm{mg} / \mathrm{l}$ and it represented acceptable concentration. A gradual reduction in the pollution load was attendant with the increase in algal growth, Table 2 and Figure 1. In the first step in our investigation we found that population $\mathrm{B}$ achieved the best growth rate $1.44-0.8$ ( $\mu$ /day) from day 2 to the end of the test and also the best growth index (31.1), Table 2 which was more related to control values (population $\mathrm{D}$ with growth rate $1.33-0.8(\mu /$ day) from day 2 to the end of the test and growth index (24.6).

The pollution load of the wastewater after inoculation by algal cells was measured on the 2 d, 6 th, 10th, 14th, 18th, 
22th, 26th and 30th days of algal growth. Measurement of physicochemical parameters on 30th day showed substantial reduction in the level of BOD, COD, TN and TP concentrations with removal percent 92.7, 87.5,100 and $100 \%$, respectively, and obvious increase in DO concentration with percent $89.1 \%$, Figure 1. This is Compatible with the results from the investigation of Adey et al. [25] as he reported that the alga Chlorella vulgaris, reduced ammonium by $72 \%$, phosphorus by $82 \%$, and COD by $61 \%$. Similar results were also obtained on sewage water treatment by using phycoremediation [26]. In reported papers, Colak and Kaya [27] studied the removal potential of nutrients of Chlorella vulgaris. They found that the removal efficiency reached (50.2\%) for nitrogen and $(85.7 \%)$ for phosphorus in industrial wastewater treatment and $(97.8 \%)$ for phosphorus in domestic wastewater and also for BOD and COD which reached $68.4 \%$ and $67.2 \%$, respectively. Lau et al. [28] also recorded that, nutrient removal efficiency reached $86 \%$ of nitrogen and $70 \%$ of phosphorus. This reduction in nutrient concentration, BOD and COD and the increase in DO concentration were due to the effective growing of microalgae through the photosynthesis process and the complex symbiosis of algae and bacteria in the nutrientrich environment [29].

Table 2: Specific growth rate $(\mu /$ day) of microalgae during test duration

\begin{tabular}{llccc}
\hline Time & \multicolumn{4}{c}{ Specific growth rate $(\mu$ /day $)$} \\
\cline { 2 - 5 } & $\boldsymbol{A}$ & $\boldsymbol{B}$ & $\boldsymbol{C}$ & $\boldsymbol{D}$ \\
\hline Day2 & 1.1 & 1.44 & 1.09 & 1.33 \\
Day6 & 1.28 & 1.17 & 1.17 & 1.22 \\
Day10 & 0.75 & 0.97 & 0.69 & 0.80 \\
Day14 & 0.85 & 0.97 & 0.75 & 0.89 \\
Day18 & 0.804 & 1.33 & 0.93 & 1.17 \\
Day22 & 0.81 & 1.41 & 0.75 & 1.35 \\
Day26 & 0.55 & 1.04 & 0.45 & 0.97 \\
Day30 & 0.34 & 0.80 & 0.20 & 0.80
\end{tabular}

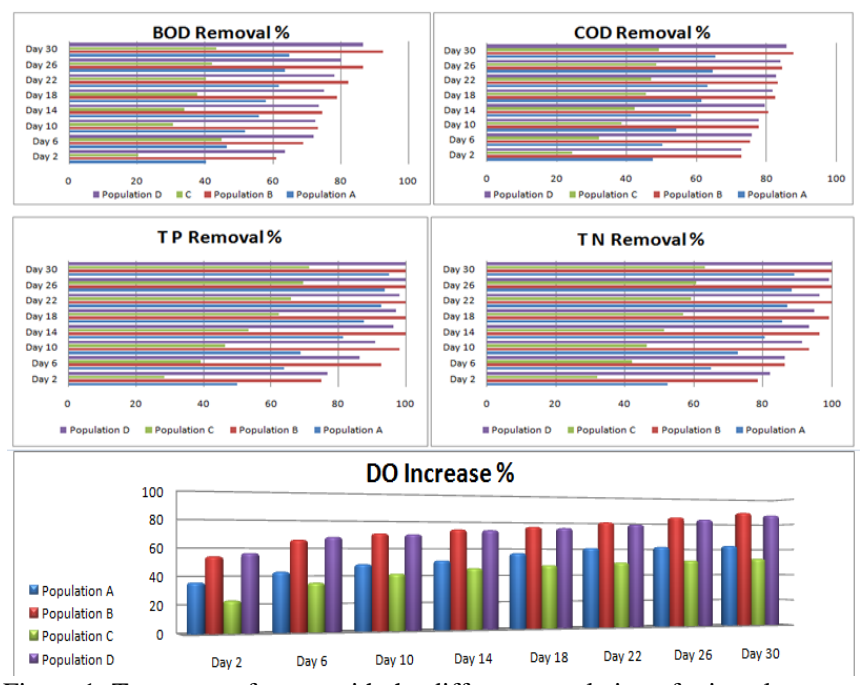

Figure 1: Treatment of water with the different population of microalgae.
In Figure 2, the $\mathrm{pH}$ value decreased gradually from 8.2 in the beginning of the investigation to 6.8 at the end of treatment. This due to the removal of various salts or metallic ions and also due to decomposition of organic matter which increased by microbial activities, [26]. Opposite observation was reported by Ezenweani et al. [3] as he founded that $\mathrm{pH}$ increase in case of usage of macroalgae and he up that to algal photosynthesis where $\mathrm{CO}_{2}$ and $\mathrm{H}^{+}$ions removed when the algae are carbon limited.

\section{Treatment with macroalgae}

There were very limited studies that focused on the usage of macroalgae in TDS, Salinity, Conductivity, Turbidity, BOD and COD removal from wastewater while the majority focused on the removal of heavy metals, [30]. In this study, macroalgae achieved close results to microalgae in the wastewater treatment, Figure 3. The biosorption potential percent of Turbinaria ornata was 44.4, 29.3, $37.8,84.2,65.3,67.5,67.1$, and $67.8 \%$ for TDS, Salinity, Conductivity, Turbidity, BOD, COD, TP and TN, respectively. While the biosorption potential percent of Dictyota dichotoma was 52.3, 39.3, 50.6, 95.3, 70.4, 71.3, 73.5 and $72.1 \%$ for TDS, salinity, conductivity, turbidity, BOD, COD, TP and TN, respectively. Simultaneously DO concentration increase with both algae, as it was $59.6 \%$ for Turbinaria ornata and $65.4 \%$ for Dictyota dichotoma.

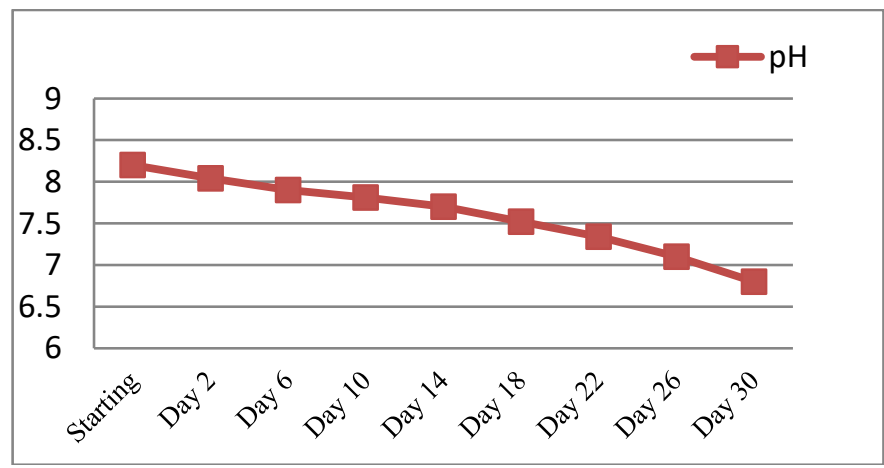

Figure 2: $\mathrm{pH}$ values during the treatment

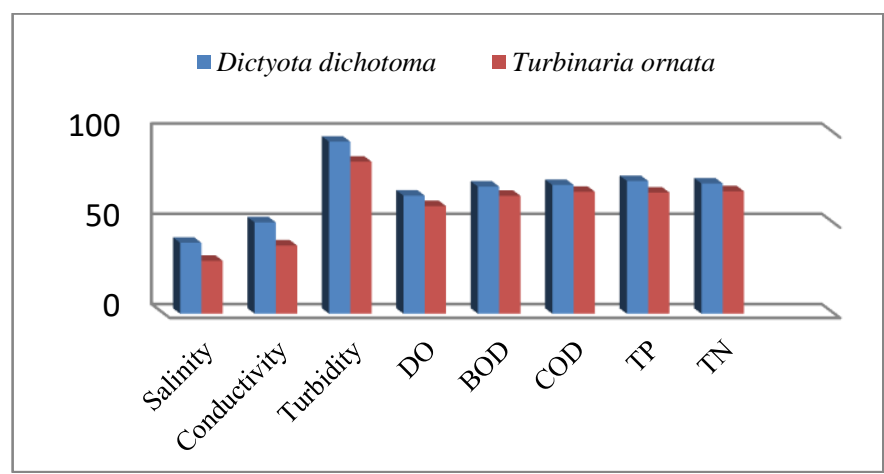

Figure 3: Biosorption potential percent of macroalgae 


\section{Treatment of heavy metals}

Chlorella and Scenedesmus are the most used microalgae for metal removal due to its efficient biotransformation ability, [32]. Abedi et al. [33] considered it a preferred option for wastewater treatment because of its rapid growth and efficient metal removal. On the other hand, marine macroalgae considered excellent biosorbents for metal uptake (Fe, Co, $\mathrm{Cu}, \mathrm{Mn}, \mathrm{Ni}, \mathrm{Zn}, \mathrm{Cd}$, and $\mathrm{Pb}$ ) especially brown algae, [34].

\section{Treatment with microalgae}

A gradual reduction was observed in the heavy metal concentration in wastewater from the beginning to the end of the test. This reduction was accompaniment to the present of algae Table 3. Best removal percent was achieved for $\mathrm{Co}, \mathrm{Fe}$ and $\mathrm{Pb}$ with close percent 99.8, 99.7, $99.5 \%$, respectively, Figure $\mathbf{4}$ with minimum and maximum metal uptake 0.1765-0.8982 mg/l, 0.6706$1.2809 \mathrm{mg} / \mathrm{l}$ and $0.6817-1.3911 \mathrm{mg} / \mathrm{l}$, respectively, Table 3. $\mathrm{Cu}$ removal percent followed that with percent $98.8 \%$ and that with minimum and maximum metal uptake 0.7501 and $1.3313 \mathrm{mg} / \mathrm{l}$. Zn removal percent reached $90.4 \%$ with minimum and maximum metal uptake 0.7398 and 1.1447 $\mathrm{mg} / \mathrm{l}$. The lowest removal was for $\mathrm{Cd}$ and $\mathrm{Ni}$ with percent 83.9 and $75.7 \%$ respectively and with minimum and maximum metal uptake $0.1282-0.3057 \mathrm{mg} / \mathrm{l}$. and $0.0224-$ $0.0742 \mathrm{mg} / \mathrm{l}$, respectively. Sengar et al. [26], reported similar results as he recorded complete removal of $\mathrm{Fe}, \mathrm{Zn}$, $\mathrm{Cu}$ and he confirmed that due to the utilization of this element by microalgae (trace elements essential to algal growth).

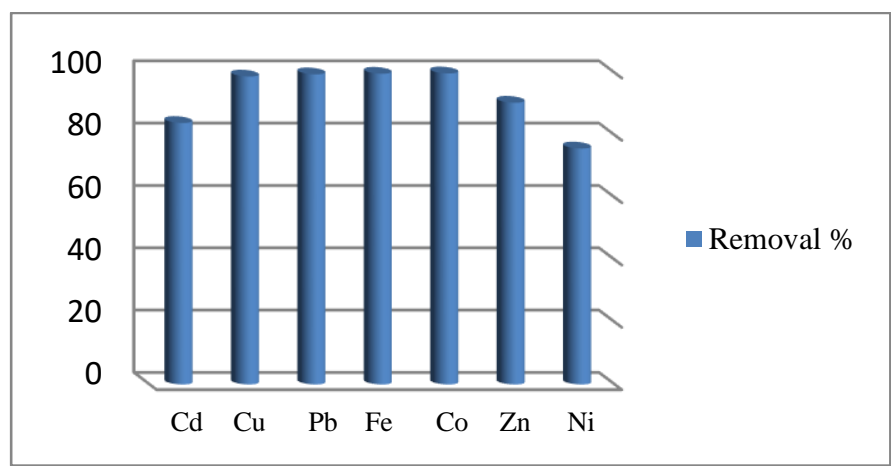

Figure 4: Heavy metal removal \% by microalgae

\section{Treatment with macroalgae}

Turbinaria ornata and Dictyota dichotoma achieved different percent of heavy metal removal, Figure 5. Although this percent was lower than the percent achieved by microalgae but, it still valuable and considerable. Turbinaria ornata recorded removal percent of 55.5, 70.9, 59.8, 57.6, 55.1, 72.6\% for $\mathrm{Cd}, \mathrm{Cu}, \mathrm{Pb}, \mathrm{Fe}, \mathrm{Co}$ and $\mathrm{Zn}$, respectively, with mean metal uptake of $0.202,0.955$, $0.835,0.739,0.495$ and $0.918 \mathrm{mg} / \mathrm{l}$, respectively. However, the lowest removal percent of $\mathrm{Ni}$ with percent $42.1 \%$ and mean metal uptake $0.041 \mathrm{mg} / \mathrm{l}$. In a similar way, Dictyota dichotoma remove $\mathrm{Ni}$ with the lowest removal percent $34.2 \%$ and mean metal uptake $0.033 \mathrm{mg} / \mathrm{l}$. $\mathrm{Zn}$ is the second-order following $\mathrm{Ni}$ as it removed by percent 40.7 and with mean metal uptake $0.346 \mathrm{mg} / \mathrm{l} . \mathrm{Cd}, \mathrm{Cu}, \mathrm{Pb}, \mathrm{Fe}$, and Co were removed with acceptable higher percent 68.3, $72.7,57.8,70.5,52.1 \%$, respectively, and that with mean metal uptake of $0.248,0.979,0.8075,0.905$ and 0.404 $\mathrm{mg} / \mathrm{l}$. Mazen [35] explains this removal potential to the cell wall which has a lot of active chemical functional groups that offer a selective interaction and binding with metals such as phenolic, hydroxyl, amine, carboxylic acid.

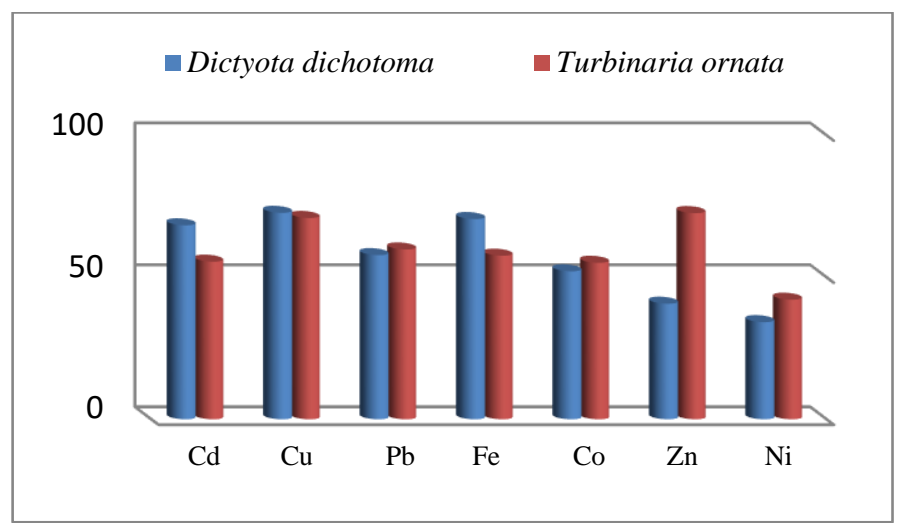

Figure 5: Heavy metal removal \% by macroalgae

\section{CONCLUSION}

Phycoremediation had become a focus of attention among researchers worldwide. This study demonstrates the ability of macro and microalgae for the removal of pollution and treating wastewater. We found that Chlorella vulgaris and Scenedesmus quadricauda as microalgae have a high potential of nutrient and metal uptake which can be used for wastewater treatment. In the same way, Turbinaria ornata and Dictyota dichotoma as macroalgae can be used as an efficient absorbent. Overall, results from this study highlighted the possibility and the need for the usage of algae as an efficient, alternative, eco-friendly and low-cost technique to remediate wastewater and it can also be used as energy source due to the ability to convert the biomass generated from treatment into different forms of bioenergy ( biogas, biodiesel, and bio-hydrogen), [32].

\section{ACKNOWLEDGEMENTS}

The authors would like to express deepest appreciation to all those who provided us the possibility to complete this research. Thank the support of the staff members and colleagues of the Environmental Sciences Department, Faculty of Science, Damietta University and special thanks go also to Botany and Microbiology Department, Faculty of Science, Damietta University for providing the equipment and research facilities.

\section{REFERENCE}

[1] Oilgae (2017). Oilgae Guide to Algae-based Wastewater Treatment.,1-500.

[2] John J. (2000). A self-sustainable remediation system for acidic mine voids. 4th International Conference of Diffuse Pollution., 506-511.

[3] Ezenweani R. S., Ogbebor J. U and Opule O. C. (2018). Phycoremediation: An Eco-Solution to Environmental 
Protection and Sustainable Remediation Journal of Chemical, Environmental and Biological Engineering., 2(1): 5-10.

[4] Fu F and Wang Q. (2011). Removal of heavy metal ions from wastewaters: A review. Journal of Environmental Management., 92(3):407-418.

[5] Brennan $\mathbf{L}$ and Owende P. (2010). Biofuels from microalgae - a review of technologies for production, processing, and extractions of biofuels and co-products. Renew Susta in Energy Rev., 14:557-77.

[6] Keffer J. E and Kleinheinz G. T. (2002). Use of Chlorella vulgaris for $\mathrm{CO}(2)$ mitigation in a photobioreactor. JInd Microbio l Biotechnol .,29:275-80.

[7] Aslan S and Kapdan I. K. (2006). Batch kinetics of nitrogen and phosphorus removal from synthetic wastewater by algae. Ecoligical Enggineering.,28:64-70.

[8] González L. E., Cañizares R. O and Baena S. (1997). Efficiency of ammonia and phosphorus removal from a colombianagro industrial wastewater by the microalgae Chlorella vulgaris and Scenedesmusdimorphus. Bioresour Technology., 60: 259-62.

[9] Herrero R., Cordero B., Lodeiro P., Rey-Castro C and Vicente M. E. (2006). Interactions of cadmium (II) and protons with dead biomass of marine algae Fucus sp. Marine Chemistry., 99:106-116

[10] Vigneshwaran C., Surendhar A., PrakashKumar B. G and Velmurugan S. (2016). Environmental Sustainability using Green Technologies, Algal Biosorption of Heavy Metals. CRC publishers., 132-143.

[11] Valentin P and Irina V. (2018). Biomass as Renewable Raw Material to Obtain Bioproducts of High-tech Value, Macroalgae biomass as Sorbent for metal ions. Elsevier B.V., 70-106

[12] Yasser H., Rezgui A., Ben D. A and Taoufik B. (2015). Removal of cadmium(II) from aqueous solutions by biosorption onto the brown macroalga (Dictyota dichotoma). Desalination and Water Treatment., 54: 1663-1673.

[13] Senthilkumar R., Vijayaraghavan K., Thilakavathi M., Iyer P. V. R and Velan M. (2007). Application of seaweeds for the removal of lead from aqueous solution. Biochemical Engineering Journal., 33(3): 211-216

[14] EPA (2009). Industrial Waste Resource guidelines sampling and analysis of waters (IWRG). Wastewaters, Soils and Wastes. Publication IWRG701 - June 2009.

[15] APHA (2012). Standard Methods for the Examination of Water and Wastewater. 19th edition, American Public Health Association (APHA), American Water Works Association (AWWA) and Water Pollution Control Federation (WPCF), Washington, D.C.

[16] Adams V. D. (1991). Water and Wastewater Examination Manual. Lewis Publishers, INC., Michigan, USA.

[17] Rump H. H. (1999). Manual for the Examination of Water, Wastewater and soil. 3rd edition, Wiley-VCH Publishers, INC, (Wiley-VCH Verlag GmbH), Weinheim, Germany.

[18] Bischoff H. W and Bold H. C. (1963). Phycological studies IV. Some soil algae from Enchanted Rock and related algal species. University of Texas Publication., 6318: (1)-95.

[19] Gani P., Sunar N. M., Matias-Peralta H., Abdul Latiff A. A and Abdul Razak A. R. (2016). Influence of initial cell concentrations on the growth rate and biomass productivity of microalgae in domestic wastewater. Applied Ecology and Environmental Research., 14(2): 399-409.

[20] Kothari R., Prasad R., Kumar V and Singh D.P. (2013) Production of biodiesel from microalgae Chlamydomona $s p$ olypyrenoideum grown on dairy industry wastewater. Bioresource Technology., 144: 499-503.

[21] Komolafe O., Velasquez-Orta S. B., Monje-Ramirez I. Yáñez Noguez I., Harvey A.P and Orta Ledesma M.T. (2014). Biodiesel production from indigenous microalgae grown in wastewater. Bioresource Technology., 154: 297-304.

[22] Eze V. C., Velasquez-Orta S. B., Hernández-García A., Monje-Ramírez I. and Orta-Ledesma M. T. (2018). Kinetic modelling of microalgae cultivation for wastewater treatment and carbon dioxide sequestration. Algal Research., 32:131-141.

[23] Suparna R. and Anantharaman P. (2017). Heavy Metals Accumulation of Different Parts of Turbinaria spp. along the Olaikuda Coast, Rameshwaram, Tamilnadu, India.
International Advanced Research Journal in Science, Engineering and Technology., 4 (3): 99-102.

[24] Environmental Quality Act, (1974). Department of Environmental, Malaysia. Available at: http://www.agc.gov.my/Akta/Vol.\%203/Act\%20127.pdf

[25] Adey, W. H., Luckett, C., Smith, M. (1996). Purification of industrially contaminated groundwater using controlled ecosystems. Ecological Engineering., 7 (3): 191-212.

[26] Sengar R. M. S., Singh K. K and Surenda S. (2011). Application of phicoremediation technology in the treatment of sewage water to reduce pollution load. Indian journal of science and research., 2(4):33-39

[27] Colak O and Kaya Z. (1988). A study on the possibilities of biological wastewater treatment using algae. Doga Biyolji Serisi., 12 (1): 18-29.

[28] Lau P. S., Tam N. F. Y and Wong Y. S. (1996). Wastewater nutrients removal by Chlorella vulgaris: optimization through acclimation. Environmental Technology., 17 (2): 183-189.

[29] Kothari R., Pathak V. V., Kumar V and Singh D. P. (2012). Experimental study for growth potential of unicellular alga Chlorella pyrenoidosa on dairy waste water: An integrated approach for treatment and biofuel production. Bioresource Technology., 116: 466-470.

[30] Arumugam N., Chelliapan S., Kamyab H., Thirugnana S., Othman $\mathbf{N}$ and Nasri N. (2018). Treatment of Wastewater Using Seaweed: A Review. International Journal of Environmental Research and Public Health., 15(12) : 2851

[31] Suresh Kumar K., Dahms H. U., Won E. J., Lee J. S and Shin K. H. (2015). Microalgae - A promising tool for heavy metal remediation. Ecotoxicology and Environmental Safety., 113:329-352.

[32] de-Bashan L. E and Bashan Y. (2010). Immobilized microalgae for removing pollutants: Review of practical aspects. Bioresource Technology., 101(6):1611-1627.

[33] Abedi S., Astaraei F. R., Ghobadian B., Tavakoli O., Jalili H., Greenwell H. C and Chivasa S. (2019). Decoupling a novel Trichormus variabilis-Synechocystis sp. interaction to boost phycoremediation. Scientific Reports., 9(1).

[34] Brinza L., Dring M and Gavrilescu M. (2007). Marine micro and macro algal species as biosorbents for heavy metals. Environmental engineering and management journal.,6. 237251.

[35] Mazen K. N. (2019). Marine Algae Bioadsorbents for Adsorptive Removal of Heavy Metals, Advanced Sorption Process Applications, Intech Open., 1-14.

[36] Zhang T. Y., Wu Y. H., Zhu S., Li F. M and Hu H. Y. (2013). Isolation and heterotrophic cultivation of mixotrophic microalgae strains for domestic wastewater treatment and lipid production under dark condition. Bioresource Technology., 149: 586-589. 
Table 1 : Characteristics of the raw domestic wastewater used as the growth media.

\begin{tabular}{|c|c|c|c|c|c|c|c|}
\hline \multirow[t]{2}{*}{$\begin{array}{c}\text { Physiochemical } \\
\text { parameters } \\
(\mathrm{mg} / \mathrm{l})\end{array}$} & \multirow[t]{2}{*}{$\begin{array}{c}\text { Present } \\
\text { study } \\
2019 \\
\end{array}$} & \multirow{2}{*}{$\begin{array}{r}\text { Gani et al. } 2016 \\
\text { Standard } 1\end{array}$} & \multicolumn{2}{|c|}{ Kothari et al. 2012} & \multicolumn{3}{|c|}{$\begin{array}{c}\text { Effluent standard, mg/L } \\
\text { (Environmental Quality Act, 1974) }\end{array}$} \\
\hline & & & Standard 2 & Standard & 3 & Standard 4 & Standard 5 \\
\hline pH & 8.2 & 6.93 & 6.2 & 7.3 & & $5.5-9.0$ & $6.0-9.0$ \\
\hline DO & 6.53 & 14.76 & - & - & & 10 & 5 \\
\hline BOD & 23.37 & 44 & - & - & & 50 & 20 \\
\hline COD & 62.55 & 76.10 & - & - & & 100 & 50 \\
\hline $\mathbf{T P}$ & 2.8 & 3.27 & 21 & 3.4 & & - & - \\
\hline $\mathbf{T N}$ & 1.4 & 15.79 & 67.35 & 15.16 & & - & - \\
\hline TDS & 40.3 & 49 & 90 & 40 & & - & - \\
\hline
\end{tabular}

Table 3: Heavy metal removal $\%$ by microalgae

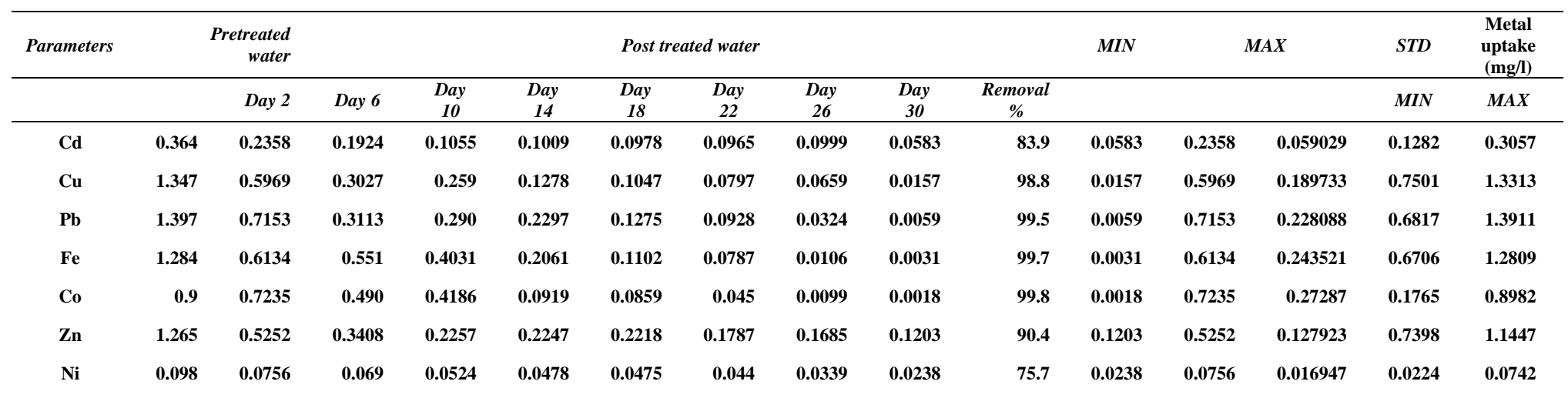

